\title{
RELATIONSHIP BETWEEN SERUM VITAMIN E LEVELS AND SERUM CHOLESTEROL IN NORMAL ADULTS IN RURAL REGIONS OF YAMAGATA PREFECTURE, JAPAN
}

\author{
Hideya Shitara, Katsumi Uruno, Yuichi TaKahashi, \\ Shoko MAISHI, ${ }^{1}$ and Shuichi KIMURA ${ }^{2}$ \\ ${ }^{1}$ Yamagata Prefectural Institute of Public Health, Yamagata, Japan \\ ${ }^{2}$ Laboratory of Nutrition, Faculty of Agriculture, Tohoku University, Sendai, Japan
} (Received October 30, 1975)

\begin{abstract}
Summary Serum vitamin E and cholesterol levels were determined for the residents in rural regions of Yamagata Prefecture, Japan. The average serum vitamin $\mathrm{E}$ were $0.99 \pm 0.25 \mathrm{mg} / 100 \mathrm{ml}$ in $166 \mathrm{men}$, and $1.06 \pm 0.26 \mathrm{mg} / 100 \mathrm{ml}$ in 178 women. Only $0.6 \%$ of the subjects were below $0.5 \mathrm{mg} / 100 \mathrm{ml}$. There was a significant difference between the serum vitamin E levels of men and women. However there were no statistically significant differences among serum vitamin $\mathrm{E}$ of various age groups. The best correlation for serum vitamin $\mathrm{E}$ was found with serum cholesterol.
\end{abstract}

The susceptibility of red blood cells to hemolysis due to dialuric acid or hydrogen peroxide was observed to increase with vitamin $\mathrm{E}$ deficiency in human beings $(1,2)$. Several investigators have reported on vitamin $\mathrm{E}$ levels in normal adults in assessing the nutritional status with regard to this vitamin (3-6). In Japan, no investigation have been reported on blood vitamin E levels in normal adults except for a few investigations on infants and children $(7,8)$. Recently a relationship between vitamin $E$ and cholesterol levels have been reported in normal adults by DeSAI and LeE (9) and Lewis et al. (10).

In this report, we present the results of the survey on serum vitamin E levels in normal adults in rural regions in Japan, and a correlation between serum vitamin $\mathrm{E}$ and serum cholesterol.

\section{METHODS}

The study population consisted of 344 persons from three rural regions, Kaneyama area (72 men, 69 women), Kawanishi area (51 men, 61 women) and 
Shirataka area (43 men, 48 women), in Yamagata Prefecture, Japan. These regions belong mainly to a rice-cultivating district. There were 166 men and 178 women ranging in age from 18 to 60 years. Blood collection was carried out before breakfast. The serum was separated and frozen until further analysis. Serum vitamin E was determined by Thompson's fluorometric method modified by ABE and KATsui (11) $1.0 \mathrm{ml}$ absolute EtOH was added to a mixture of $0.2 \mathrm{ml}$ serum and $1.0 \mathrm{ml}$ distilled water and shaken vigorously and followed by the addition of $5.0 \mathrm{ml} n$-hexane. After vigorous shaking for one minute, the extracted vitamin $\mathrm{E}$ in the $n$-hexane layer was determined fluorometrically: excitation $295 \mathrm{~nm}$, emission $320 \mathrm{~nm}$. Serum total cholesterol was determined with a cholesteroltest kit using a modified Zak-Henly method $(12,13)$.

\section{RESULTS AND DISCUSSION}

The mean serum vitamin $\mathrm{E}$ levels are presented in Table 1. The mean serum vitamin E concentration and standard deviation in milligrams per $100 \mathrm{ml}$ for the entire survey were $0.99 \pm 0.25$ with a range of 0.57 to 1.77 in men, and $1.06 \pm 0.26$

Table 1. Mean serum vitamin $\mathrm{E}$ levels in normal adults.

\begin{tabular}{|c|c|c|c|c|c|c|c|c|}
\hline \multirow[b]{2}{*}{ Area } & \multicolumn{4}{|c|}{ Men } & \multicolumn{4}{|c|}{ Women } \\
\hline & $n$ & Av. \pm S.D. & Min. & Max. & $n$ & Av. \pm S.D. & Min. & Max. \\
\hline Kaneyama & 72 & $0.99 \pm 0.27$ & 0.66 & 1.77 & 69 & $1.05 \pm 0.23$ & 0.58 & 2.05 \\
\hline Kawanishi & 51 & $1.03 \pm 0.24$ & 0.65 & 1.57 & 61 & $1.14 \pm 0.28$ & 0.70 & 1.84 \\
\hline Shirataka & 43 & $0.94 \pm 0.22$ & 0.57 & 1.39 & 48 & $0.99 \pm 0.24$ & 0.38 & 1.54 \\
\hline Total & 166 & $0.99 \pm 0.25$ & 0.57 & 1.77 & 178 & $1.06 \pm 0.26$ & 0.38 & 2.05 \\
\hline
\end{tabular}

$n$, number of sample; Av, average $(\mathrm{mg} / 100 \mathrm{ml}) ;$ S.D., standard deviation.

with a range of 0.38 to 2.05 in women respectively. HARRIS et al. (3) have reported average plasma vitamin E levels in Rochester, New York, of $1.05 \pm 0.32$ $\mathrm{mg} / 100 \mathrm{ml}$. BiERI et al. (4) found an average of $1.05 \pm 0.26 \mathrm{mg} / 100 \mathrm{ml}$ in 132 normal adults in Washington D.C. DeSAI (5) found an average of $0.97 \pm 0.29$ $\mathrm{mg} / 100 \mathrm{ml}$ in 379 normal adults residing in metropolitan Vancouver and in the nearby rural community of Chillwack. Similar vitamin E levels were obtained in our investigation in comparison with these reports and others (6). There was significant difference between the serum vitamin $\mathrm{E}$ levels of men and women. The frequency distributions of this vitamin levels in men and women are presented in Table 2. Only $0.6 \%$ of the subjects were below $0.5 \mathrm{mg} / 100 \mathrm{ml}$. About $37.4 \%$ of the men and $23.1 \%$ of the women were below $0.9 \mathrm{mg} / 100 \mathrm{ml}$, while about $26.2 \%$ of the men and $37.0 \%$ of the women were above $1.1 \mathrm{mg} / 100 \mathrm{ml}$. Table 3 shows average serum vitamin $\mathrm{E}$ and cholesterol levels of men and women ranging in age from 18 to 60 years. It has been reported that there was a tendency for 
Table 2. Frequency distribution of serum vitamin $\mathrm{E}$ in normal adults.

\begin{tabular}{|c|c|c|c|c|c|c|}
\hline \multirow{2}{*}{$\begin{array}{l}\text { Range of serum } \\
\text { vitamin } E \text { levels } \\
(\mathrm{mg} / 100 \mathrm{ml})\end{array}$} & \multicolumn{2}{|c|}{ Men } & \multicolumn{2}{|c|}{ Women } & \multicolumn{2}{|c|}{ Total } \\
\hline & $\begin{array}{c}\text { Frequency } \\
(\%)\end{array}$ & $\begin{array}{l}\text { No. in } \\
\text { group }\end{array}$ & $\begin{array}{c}\text { Frequency } \\
(\%)\end{array}$ & $\begin{array}{l}\text { No. in } \\
\text { group }\end{array}$ & $\begin{array}{c}\text { Frequency } \\
(\%)\end{array}$ & $\begin{array}{l}\text { No. in } \\
\text { group }\end{array}$ \\
\hline $0.300-0.399$ & - & - & 0.6 & 1 & 0.3 & 1 \\
\hline $0.400-0.499$ & - & - & 0.6 & 1 & 0.3 & 1 \\
\hline $0.500-0.599$ & 1.2 & 2 & 1.1 & 2 & 1.2 & 4 \\
\hline $0.600-0.699$ & 7.2 & 12 & 2.8 & 5 & 4.9 & 17 \\
\hline $0.700-0.799$ & 14.5 & 24 & 5.6 & 10 & 9.9 & 34 \\
\hline $0.800-0.899$ & 14.5 & 24 & 12.4 & 22 & 13.4 & 46 \\
\hline $0.900-0.999$ & 16.9 & 28 & 23.6 & 42 & 20.3 & 70 \\
\hline $1.000-1.099$ & 20.5 & 34 & 16.3 & 29 & 18.3 & 63 \\
\hline $1.100-1.199$ & 8.4 & 14 & 11.2 & 20 & 9.9 & 34 \\
\hline $1.200-1.299$ & 3.6 & 6 & 11.2 & 20 & 7.6 & 26 \\
\hline $1.300-1.399$ & 4.8 & 8 & 5.6 & 10 & 5.2 & 18 \\
\hline $1.400-1.499$ & 3.6 & 6 & 1.7 & 3 & 2.6 & 9 \\
\hline $1.500-1.599$ & 3.6 & 6 & 3.9 & 7 & 3.8 & 13 \\
\hline $1.600-1.699$ & 0.6 & 1 & - & - & 0.3 & 1 \\
\hline $1.700-1.799$ & 0.6 & 1 & 2.2 & 4 & 1.5 & 5 \\
\hline $1.800-1.899$ & - & - & 0.6 & 1 & 0.3 & 1 \\
\hline $1.900-1.999$ & - & - & - & - & - & - \\
\hline $2.000-2.099$ & - & - & 0.6 & 1 & 0.3 & 1 \\
\hline Total & 100 & 166 & 100 & 178 & 100 & 344 \\
\hline
\end{tabular}

Table 3. Mean values and standard deviation of serum vitamin $\mathrm{E}$ and serum cholesterol in age groups.

\begin{tabular}{clccccc}
\hline \multicolumn{2}{c}{ Range of age (years) } & $18-19$ & $20-29$ & $30-39$ & $40-49$ & $50-60$ \\
\hline Sample No. & Men & 12 & 37 & 26 & 56 & 35 \\
& Women & 3 & 32 & 35 & 68 & 39 \\
\hline Average & Men & 18.3 & 24.1 & 34.7 & 45.0 & 54.4 \\
of age & Women & 18.3 & 24.1 & 34.9 & 44.3 & 54.3 \\
\hline Vitamin E & Men & $0.90 \pm 0.18$ & $1.02 \pm 0.25$ & $0.95 \pm 0.20$ & $1.05 \pm 0.26$ & $0.96 \pm 0.23$ \\
$(\mathrm{mg} / 100 \mathrm{ml})$ & Women & $0.95 \pm 0.32$ & $1.11 \pm 0.22$ & $0.98 \pm 0.30$ & $1.08 \pm 0.25$ & $1.07 \pm 0.24$ \\
\hline Cholesterol & Men & $144 \pm 15$ & $150 \pm 19$ & $140 \pm 19$ & $154 \pm 23$ & $150 \pm 21$ \\
$(\mathrm{mg} / 100 \mathrm{ml})$ & Women & $167 \pm 19$ & $160 \pm 24$ & $145 \pm 20$ & $160 \pm 20$ & $168 \pm 24$ \\
\hline
\end{tabular}

Table 4. Coefficients of correlation for serum vitamin $\mathrm{E}$ to serum cholesterol in normal adults.

\begin{tabular}{lcc}
\hline \multicolumn{1}{c}{ Area } & Men & Sex \\
\hline Kaneyama & $0.392(72)^{*}$ & Women \\
Kawanishi & $0.263(51)$ & $0.475(69)^{*}$ \\
Shirataka & $0.632(43)^{*}$ & $0.488(61)^{*}$ \\
Total & $0.323(166)^{*}$ & $0.512(48)^{*}$ \\
\hline
\end{tabular}

* $p<0.001 ;(n)$, number of person. 
the average serum vitamin $E$ to increase with age $(5,6,9,10)$. In our subjects, there were no correlation for these vitamin levels to age. The nationwide investigation on serum cholesterol levels in normal adults in Japan indicates that serum cholesterol levels increase with age and that serum cholesterol levels in the residents in cities were higher than in rural regions (14). In our survey, no increase of serum cholesterol levels with age was observed, and serum cholesterol levels were lower in comparison with the average of whole country of Japan. Coefficients of correlation for serum vitamin $\mathrm{E}$ to serum cholesterol are presented in Table 4. Correlation of this vitamin to cholesterol were statistically significant at $0.1 \%$ levels of probability except for men in the Kawanishi area. BAKER et al. (15) indicate that plasma vitamin $\mathrm{E}$ is associated with the $\beta$-lipoprotein fraction, which is also a common carrier of plasma cholesterol. Recently DeSAI and LEE (9) found the best correlation for plasma vitamin E with plasma cholesterol and age. In our investigation, there were also statistically significant correlation for serum vitamin $\mathrm{E}$ with serum cholesterol. On the other hand, there was no increase of serum vitamin $\mathrm{E}$ and cholesterol with age. These results seem to support that the relationship between serum vitamin $\mathrm{E}$ and cholesterol reflects a close association with serum $\beta$-lipoprotein fraction.

\section{REFERENCES}

1) Horwitt, M. K., Am. J. Clin. Nutr., 8, 451 (1960).

2) HoRwitT, M. K., Borden's Rev. Nutr. Res., 22, 1 (1961).

3) Harris, P. L., Hardenbrook, E. G., Dean, F. P., Cusack, E. R., and Jensen, J. L., Proc. Soc. Exptl. Biol. Med., 107, 381 (1961).

4) Bieri, J. G., Teets, L., Belavady, B., and Andrews, E. L., Proc. Soc. Exptl. Biol. Med., 117, 131 (1964).

5) Desai, I. D., Can. J. Physiol. Pharmacol., 46, 819 (1968).

6) Leitner, Z. A., Moore, T., and Sharman, I. M., Brit. J. Nutr., 14, 281 (1960).

7) Kuratani, H., Acta Paediatrica Japonica, 70, 377 (1966).

8) Mino, M. and Sugawara T., Jap. J. Pediatrice, 17, 167 (1964).

9) Desai, I. D. and Lee, M., Am. J. Clin. Nutr., 27, 334 (1974).

10) Lewis, J. S., Pian, A. K., Baer, M. T., Acosta, P. B., and Emerson, G. A., Am. J. Clin. Nutr., 26, 136 (1973).

11) ABe, K. and Katsui, G., J. Jap. Soc. Food and Nutr., 28, 277 (1975).

12) ZAK, B., Am. J. Clin. Path., 27, 583 (1957).

13) HeNLY, A. A., Analyst., 82, 286 (1957).

14) OKINAKA, S., Epidemiological and pathological aspects of coronary artery disease in Japan. Ann. New York Acad. Sci., 97, 920 (1963).

15) Baker, H., Frank, O., Feingold, S., and Leevy, C. M., Nature, 215, 84 (1967). 